\title{
Eugenia goiapabana (Myrtaceae), a New Species from Espírito Santo, Brazil
}

\author{
Marcos Sobral \\ Departamento de Ciências Naturais, Universidade Federal de São João del-Rei, Praça Dom \\ Helvécio 74, 36301-360 São João del-Rei, Minas Gerais, Brazil. marcos_sobral@hotmail.com \\ Fiorella Fernanda Mazine \\ Departamento de Botânica, Universidade Federal de São Carlos, Caixa Postal 676, 13565-905 \\ São Carlos, São Paulo, Brazil. fiorella@ufscar.br
}

AвstRact. Eugenia goiapabana Sobral \& Mazine, a new species of Myrtaceae from Espírito Santo, eastern Brazil, is described, illustrated, and has its conservation status evaluated. The new species morphologically resembles E. bocainensis Mattos, from which it differs by its glabrous, acute leaves, racemiform inflorescences, and glabrous calyx lobes.

Resumo. Eugenia goiapabana Sobral \& Mazine, uma nova espécie de Myrtaceae do estado brasileiro de Espírito Santo, é descrita, ilustrada e avaliada quanto a sua conservação. A nova espécie é próxima de E. bocainensis Mattos, da qual se distingue pelas folhas glabras de ápice agudo, inflorescências racemiformes e lobos do cálice glabros.

Key words: Brazil, Espírito Santo, Eugenia, IUCN Red List, Myrtaceae.

Eugenia L. (Myrtaceae) is a widespread tropical genus with about 350 species in Brazil (Govaerts et al., 2010). The genus is especially frequent in the Atlantic coastal rainforests in Brazil (Thomaz \& Monteiro, 1997; Negrelle, 2002; Amorim et al., 2005; Jesus \& Rolim, 2005). During our examination of collections from the montane rainforests in central Espírito Santo, we found a distinctive species of Eugenia that we here propose as new.

Eugenia goiapabana Sobral \& Mazine, sp. nov. TYPE: Brazil. Espírito Santo: Mun. Santa Teresa, Nova Lombardia, Reserva Biol. Augusto Ruschi, Tracomal, 19 Dec. 2002, R. R. Vervloet, E. Bausen \& W. Pizziolo 1580 (holotype, MBML; isotype, BHCB). Figure 1.

Species haec Eugeniae bocainensi Mattos proxima, a qua foliis glabris discoloribus apice acutis, inflorescentiis racemiformibus et bracteolis calyceque glabris recedit.

Tree 5-10 m tall; plants with scattered simple trichomes to $0.2 \mathrm{~mm}$ on the abaxial surface of young blades and densely appressed trichomes to $0.1 \mathrm{~mm}$ on the ovaries and occasionally on the inflorescences. Petioles 6-10 × 1-1.2 mm. Leaf blades narrowly elliptic to lanceolate, $45-85 \times 15-40 \mathrm{~mm}$, discolorous, somewhat dull abaxially, translucid glandular dots $<$ $0.1 \mathrm{~mm}$ diam., ca. 30 per $\mathrm{mm}^{2}$, occasionally visible on both sides, apex acute to broadly acute, base cuneate; midvein plane or sulcate adaxially and convex abaxially; lateral veins 15 to 18 per side, departing at $60^{\circ}-70^{\circ}$ from the midvein, scarcely visible adaxially and faint abaxially; marginal vein $1-2.5 \mathrm{~mm}$ from the margin, occasionally a second marginal vein $0.2-0.5$ $\mathrm{mm}$ from margin. Inflorescences terminal, racemiform, with 4 to 6 flowers, the axis 20-30 × 1-2 mm, sometimes with densely appressed ochraceous, arachnoid trichomes to $0.1 \mathrm{~mm}$; pedicels $5-10 \times 0.8-1 \mathrm{~mm}$; bracteoles glabrous, widely ovate to cordate, $6-8 \times 4-$ $6 \mathrm{~mm}$, persisting after anthesis; flower buds not seen. Ovary externally densely covered with appressed ochraceous, arachnoid trichomes to $0.1 \mathrm{~mm}$; calyx lobes glabrous, unequal, the external ones ovate, $6-7 \times$ ca. $5 \mathrm{~mm}$, the internal ones elliptic or ovate-elliptic, 7-9 $\times 4-6 \mathrm{~mm}$, widely spreading at anthesis, the margin sometimes slightly revolute; petals rounded or widely ovate, $9-10 \times$ ca. $8 \mathrm{~mm}$, somewhat fleshy, as thick as the calyx lobes; stamens 150 to 180 , filaments $6-9 \mathrm{~mm}$, anthers oblong or elliptic-ovate, to $1 \times 0.5 \mathrm{~mm}$, with 1 apical gland to $0.1 \mathrm{~mm}$ and 1 to 3 glands to $0.05 \mathrm{~mm}$ adaxially; staminal ring subquadrate to $5 \mathrm{~mm}$ diam.; style to $10 \mathrm{~mm}$, stigma punctiform and papillose, papillae $<0.05 \mathrm{~mm}$; ovary 2-locular, ovules 16 to 20 per locule. Fruits globose, yellow when mature, 12$16 \mathrm{~mm}$ diam.; seeds reniform, 11-12 $\times$ ca. $10 \mathrm{~mm}$, testa dull with a darker, slightly elevated dorsal crest to $4 \mathrm{~mm}$ wide, with cotyledons fused with no visible hypocotyl.

Distribution and habitat. Eugenia goiapabana is a small tree growing in rainforests and secondary forests in the mountainous region of central Espírito Santo, at altitudes of 800-1600 m above sea level. At 


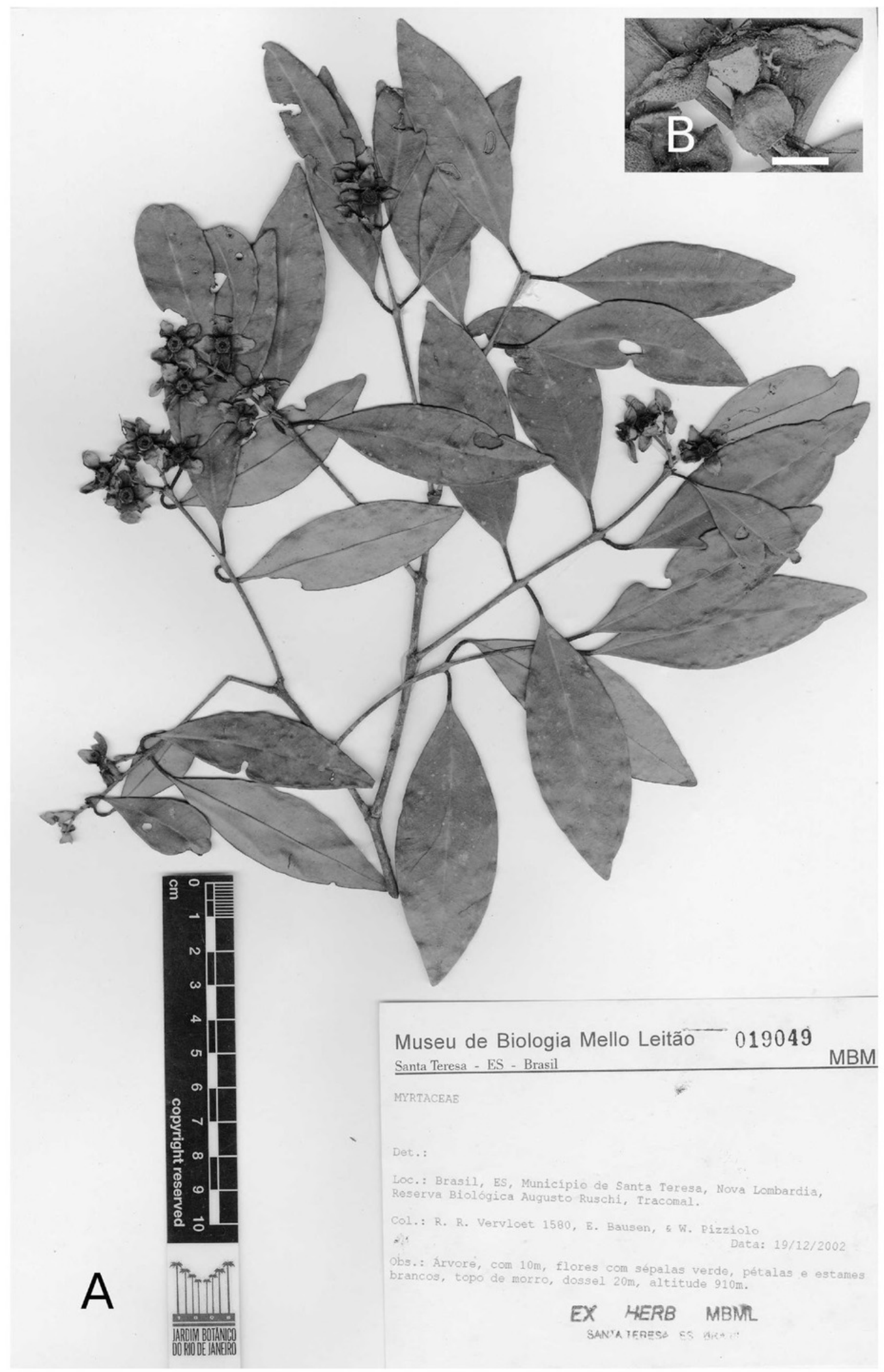

Figure 1. Eugenia goiapabana Sobral \& Mazine. - A. Isotype at BHCB. - B. Detail of flower, with one calyx lobe detached and bracteole displaced to show the externally pilose ovary. A, B taken from Vervloet et al. 1580; scale in B = $10 \mathrm{~mm}$.

present it is known from the municipalities of Fundão, Santa Teresa, and Castelo.

IUCN Red List category. Eugenia goiapabana should be considered Endangered (EN) following
IUCN Red List criteria Blab(iii) (IUCN, 2001). Its known range is less than $5000 \mathrm{~km}^{2}$ (criterion B1), since the municipalities of Castelo, Fundão, and Santa Teresa, including the area of other municipalities between them where the species was not collected but 
may possibly be found, occupy an area of ca. $3000 \mathrm{~km}^{2}$ (see data and map in IBGE, 2010). It occurs only in severely fragmented habitats (criterion a) (Aguiar et al., 2005: 121), and its habitat is in continuing decline (criterion b[iii]), since most municipalities in central Espírito Santo have been intensely deforested and only very small areas retain their original vegetation. For example, Mendes and Padovan (2000: 16) report that only $18 \%$ of the municipality of Santa Teresa still retains its original vegetation.

Phenology. Flowers were collected in December through February and fruits in March through July.

Etymology. The specific epithet is derived from the locality of Goiapaba-Açu, in the municipality of Fundão, where one of the first collections of this species was made.

Taxonomic affinities. This species appears to be related to Eugenia bocainensis Mattos (for description see Berg, 1857-1859: 592, under Phyllocalyx ligustrinus O. Berg), a species native to Rio de Janeiro, from which it is distinguished by the characters described in the following key couplet:

la. Leaf blades (at least when young) with scattered trichomes abaxially, concolorous, apex acuminate; flowers solitary or 2 per axile, without a welldeveloped axis; bracteoles pilose; flowers uniformly pilose ............ E. bocainensis

lb. Leaf blades glabrous adaxially and abaxially, discolourous, apex acute; flowers up to 6, along a visibly developed racemiform axis; bracteoles glabrous; flowers with trichomes restricted to the ovaries . . . . . . . . . Eoiapabana

Paratypes. BRAZIL. Espírito Santo: Mun. Castelo, Parque Estadual do Forno Grande, localidade de Bateias, $20^{\circ} 31^{\prime} 37^{\prime \prime} \mathrm{S}, 41^{\circ} 06^{\prime} 06^{\prime \prime W}, 13$ Feb. 2008, R. C. Forzza, C. N. Fraga, L. Kollmann, A. P. Fontana \& P. H. Labiak 4999 (BHCB, CEPEC, MBML, R, UPCB), 18 Aug. 2008, A. P. Fontana, L. Kollmann, C. N. Fraga, P. Labiak, R. Goldenberg, P. Vianna \& M. Saavedra 5419 (BHCB, CEPEC, MBML, R, UPCB); Mun. Fundão, Goiapaba-Açu, 15 July 1998, L. Kollmann, E. Bausen \& W. Pizziolo 219 (BHCB, MBML), 25 July 2000, V. Demuner 1227 (BHCB, MBML); Mun. Santa Teresa, Penha, sítio do Zurlo, 9 July 1998, L. Kollmann, E. Bausen \& W. Pizziolo 204 (BHCB, MBML); Nova Lombardia, Reserva Biol. Augusto Ruschi, 19 Dec. 2002, R. R. Vervloet, E. Bausen \& W. Pizziolo 1580 (MBML); Reserva Biol. Augusto Ruschi, divisa, represa, 21 Jan. 2003,
R. R. Vervloet, E. Bausen \& W. Pizziolo 1686 (BHCB, MBML).

Acknowledgments. We are grateful to the staff of the Museu de Biologia Mello Leitão (MBML), Santa Teresa, for their kind assistance with our work and to the collectors of the specimens cited here. We also acknowledge Neil Snow (BISH), Victoria C. Hollowell (MO), and an anonymous reviewer for their valuable suggestions and improvement of this paper, and to Rafaela Forzza and Erika von Sohsten Medeiros (RB) for their kind help in preparing the images.

\section{Literature Cited}

Aguiar, A. P., A. G. Chiarello, S. L. Mendes \& E. N. de Matos. 2005. Os corredores central e da Serra do Mar na mata atlântica brasileira. Pp. 119-132 in C. Galindo-Leal \& I. G. Câmara (editors), Mata Atlântica: Biodiversidade, Ameaças e Perspectivas. Fundação SOS Mata Atlântica/ Conservação Internacional, Belo Horizonte.

Amorim, A., P. Fiaschi, J. Jardim, W. Thomas, B. Clifton \& A. M. Carvalho. 2005. The vascular plants of a forest fragment in southern Bahia, Brazil. Sida 21: 1726-1752.

Berg, O. 1857-1859. Myrtaceae. In C. F. P. von Martius (editor), Flora Brasiliensis 14(1): 1-656. F. Fleischer, Leipzig.

Govaerts, R., M. Sobral, P. Ashton, F. Barrie, B. K. Holst, L. R. Landrum, K. Matsumoto, F. F. Mazine, E. Nic Lughadha, C. Proença, L. H. Soares-Silva, P. G. Wilson \& E. Lucas. 2010. World Checklist of Myrtaceae. The Board of Trustees of the Royal Botanic Gardens, Kew. Published on the Internet: <http://www.kew.org/wcsp/>, accessed 7 July 2010.

Instituto Brasileiro de Geografia e Estatística (IBGE). 2010. IBGE Cities@.<http://www.ibge.gov.br/cidadesat/default. php>, accessed 6 July 2010.

IUCN. 2001. IUCN Red List Categories and Criteria, Version 3.1. Prepared by the IUCN Species Survival Commission. IUCN, Gland, Switzerland, and Cambridge, United Kingdom.

Jesus, R. M. \& S. Rolim. 2005. Fitossociologia da mata atlântica de tabuleiro. Bol. Técn. Soc. Invest. Florest. 19: $1-136$.

Mendes, S. L. \& M. P. Padovan. 2000. A Estação Biológica de Santa Lúcia, Santa Teresa, Espírito Santo. Bol. Mus. Biol. Mello Leitão, Nova Sér. 11/12: 7-34.

Negrelle, R. 2002. The Atlantic forest in the Volta Velha Reserve: A tropical rain forest site outside the tropics. Biodivers. \& Conservation 11: 887-919.

Thomaz, L. D. \& R. Monteiro. 1997. Composição florística da mata atlântica de encosta da Estação Biológica de Santa Lúcia, município de Santa Teresa, ES. Bol. Mus. Biol. Mello Leitão, Nova Sér. 7: 3-48. 


\section{$2 \mathrm{BHL}$ Biodiversity Heritage Library}

Sobral, Marcos and Mazine, Fiorella Fernanda. 2010. "Eugenia goiapabana (Myrtaceae), a New Species from Espírito Santo, Brazil." Novon a journal of botanical nomenclature from the Missouri Botanical Garden 20, 348-350.

View This Item Online: https://www.biodiversitylibrary.org/item/123332

Permalink: https://www.biodiversitylibrary.org/partpdf/122038

\section{Holding Institution}

Missouri Botanical Garden, Peter H. Raven Library

\section{Sponsored by}

Missouri Botanical Garden

\section{Copyright \& Reuse}

Copyright Status: Permission to digitize granted by rights holder Rights: https://www.biodiversitylibrary.org/permissions

This document was created from content at the Biodiversity Heritage Library, the world's largest open access digital library for biodiversity literature and archives. Visit BHL at https://www.biodiversitylibrary.org. 